\title{
The Role of Environmental Economic Instruments as One of the Efforts to Prevent and Control Environmental Pollution Caused by Industrial Activities
}

\author{
Indah Dwiprigitaningtias ${ }^{1}$, Aliesa Amanita ${ }^{2}$, Zulfika Ikrardini $^{3}$, Lily Andayani ${ }^{4}$, R Ardini \\ Rakhmania Ardan ${ }^{5}$ \\ \{agisti2013@gmail.com¹,notarisaliesa@gmail.com², zulfika.ikrardini@gmail.com³, \\ Lily.risman@gmail.com ${ }^{4}$, arniardan@gmail.com ${ }^{5}$ \} \\ Program of Law FISIP University of Jenderal Achmad Yani, Indonesia ${ }^{1}$, Program of Law FISIP University of \\ Jenderal Achmad Yani, Indonesia ${ }^{2}$, Program of Law FISIP University of Jenderal Achmad Yani, Indonesia ${ }^{3}$, \\ Program of Law FISIP University of Jenderal Achmad Yani, Indonesia ${ }^{4}$, Program of Law FISIP University of \\ Jenderal Achmad Yani, Indonesia ${ }^{5}$
}

\begin{abstract}
The environmental problem is a problem that arises caused by human carelessness and indifference in the management of living environment. The development utilizes natural resources continuously to improve the public welfare so that the process of development activities is more increasing and it contains the risk of pollution and / or the living environment so that the structure and the basis function of the ecosystem as foundations of life can be damaged. Environmental pollution and / or destruction will become a social problem, at the end, it requires environmental restoration cost which is high enough. The regulation in Article 42 Section (1) of Law Number 32 of 2009 regarding environmental protection and management of living environment states that: "In order to preserve environmental functions, the government and local governments are obliged to develop and implement The Environmental Economic Instruments. In this Article 18, it states about the internalization of environmental costs, that states, "Business actors or event organizers are responsible for including production costs or business (activity) costs." These costs include the preventing of environmental pollution or damage, the monitoring of environmental pollution and damage.
\end{abstract}

Keywords: environmental problems, environmental preservation, environmental economic instruments

\section{Introduction}

The development that is being carried out in many countries has resulted various advances in various fields, both in the fields of technology, production, management and information, which all of them have improved the quality of human life, but those achievements reached have an impact on the capacity of the environmental carrying. Industrial growth in many countries, 
including Indonesia has caused environmental pollution and damage. The use and management of natural resources that are not considered in the use of it, it will cause very detrimental side effects for the environment and society. [1].

National economic development as regulated in the Article 33 Section (4) of the 1945 Constitution, it shall be carried out based on the principles of sustainability and environmental insight. Sustainable development requires an instrument to organize (power) in order to conduct and realize the sustainable development. It occurs because the human being tends to take advantage of the maximum possibility to make use of the natural resources in order to obtain benefits without considering its sustainability.

The Constitution Number 32 Year 2009 regarding Environmental Protection and Management of Environment, it regulates the instruments of Environment Economic which are divided into controlling efforts, especially in the context of preventing environmental pollution and / or environmental damage.[2]

Regulation Article 42 Section (1) of The Constitution Number 32 Year 2009 regarding Protection and Management of Environmental states that: "In order to preserve environmental functions, the government and local governments are required to develop and implement the Instruments of Environmental Economic ".

\section{Literature Review}

We discuss about environmental problem is a problem that arises as a result of human carelessness and indifference in the management of environmental. Those two things are important and related to the problem of pollution and environmental damage.[3] Environmental pollution is the inclusion or to include living things, substances, energy, or other components into the environment caused by human activities so that the quality of the environment decreases to a level that causes the environment does not have function any longer. [4]

Environmental pollution and / or damage that causes the decrease of environment, if it is not overcome early and wisely, it will lead to a major impact towards the environment both directly and indirectly, and it will affect the present and future generations and later on, it will affect the process of its development.

The development continuously utilizes natural resources to improve the society welfare and it causes the process of the development activities increases, and it contains the risk of pollution and / or the environment so that the structure and the basic function of the ecosystem as the foundation of life can be damaged. Environmental pollution and / or destruction will become a social problem, which in at the end, it requires environmental restoration cost which is high enough.

The society and businessmen awareness related to the importance of the environment should be improved. Besides that, the government also should implement good environmental governance, which means a government understands or cares about environmental aspects. Some means for realizations of the sustainable development are the development that preserves the natural resources and the environment in the present and in the future. 
Therefore, the synergy of economic and social development must be emphasized more on maximum efforts to make use the natural resources and the environment in a sustainable manner and the purpose is to maximize the increase of social welfare (maximizing social well-being).

\subsection{Pollution and Damage}

Environmental pollution and / or damage caused by industrial activities, especially the textile industry, it causes huge losses for the environment and society so that it requires high costs of environmental restoration and compensation for society.

Business actors or factory owners who pollute and / or damage the environment must be responsible for their actions by paying compensation in order to restore the functions of the environment that has been polluted and / or damaged. The large cost of recovery and compensation for the environment and society sometimes makes the industrial factory owners unable to pay. If this happens, it will be a problematic case because of whom the responsibility can be transferred because there is no guarantee or certainty for the payment of the compensation.

In this case, the society is very disadvantaged. The pollution can give impacts both material and immaterial among the society area. Material losses are losses that can be valued in currency, while immaterial losses are losses that cannot be valued in currency.

\subsection{Governer Regulation about Environmental Economics}

On November 10, 2017, there was a Government Regulation about Environmental Economics (IELH). In the Article 18, the regulation mentions the matter of internalization of environmental costs, which states, "Businessmen or event organizers are responsible for submitting the cost of production calculation or the cost of business activity." The costs include the prevention of environmental pollution or damage, the monitoring of environmental pollution and damage.

Actually, there are many government regulations that have been implemented to protect environmental preservation, but in fact, there are some shortcomings in solving the environmental problem, this condition makes the researchers want to study the instrument of environmental economic.

\section{Methodology}

In this paper, authors use qualitative methods by compare real condition with regulation government focusing on pollution. This method seeking data by comparison ways and analyze deeper about the damage of pollution that happen in industrial activity. Through comparison, authors agree that governer regulation it will be more suitable or better with condition that happen in environmental pollution. Hence, through qualitative methods, the author argues that we can read data through a pollution data with governor regulation for environmental pollution that happen 


\section{Discussion}

The environment, including its natural resources, both globally, regionally and nation in the history of human civilization, has given two meanings to humans. On one hand, the perceived meaning is that the society welfare and the quality of human life increase, and on the other hand, it causes disasters as well the decrease of human life quality.

Humans with plants, animals, and micro-organisms occupy a certain space. Besides that, there are also inanimate objects, that is, air that consists of various kinds of gases, water in the form of vapor, liquid and solid. The space occupied by living things along with non-living things is called the Environment.[5]

The environmental problem is a problem that arises caused by human carelessness and indifference in the management of environmental. Those two things are important and related to the problem of pollution and environmental destruction. Environmental pollution is the inclusion or to include living things, substances, energy, or other components into the environment by human activities so that the quality decreases to a level that causes the environment does not have function any longer.[3]

Environmental pollution and / or damage that causes the decrease of environmental quality, gradually if it is not overcome early and wisely, it will lead to a major impact on the environment both directly and indirectly, and it will affect the present and future generations, and later on, it will affect the process of the development itself. [6]

The development continuously utilizes natural resources to improve the society welfare and it causes the process of development activities is more increasing, and it contains the risk of pollution and / or the environment so that the structure and the basic function of the ecosystem as the foundation of life can be damaged. Environmental pollution and / or destruction will become a social problem, at the end, it requires the cost of environmental restoration which is high enough.

The maintenance of a sustainable environmental function is very important that requires responsibility for the society, businessmen and the government to maintain and increase the capacity of the environment. Therefore, development that integrates the environment is needed to guarantee the health and quality of life for present and future generations. So that, sustainable development that is environmentally insight is required in this development.[7]

The society and businessmen awareness related to the importance of the environment should be improved. Besides that, the government also should implement good environmental governance, which means a government understands or cares about environmental aspects. Some means for realizations of the sustainable development are the development that preserves the natural resources and the environment in the present and in the future. [8]

The Constitution No.32 of 2009 regarding The Protection and Management of Environment, it organizes the Environmental Economic instrument which is categorized into efforts to control environmental pollution and / or damage. The regulation in article 42 section (1) of The Constitution Number 32 of 2009 regarding environmental protection and management state that: "In order to preserve environmental functions, the government and local governments are obliged to develop and implement The Instruments of Environmental Economic.[2] 
The purpose of Economic Instrument is to bridge the gap between private and social costs through internalizing of all external costs (abatement and pollution costs) of depleted resources and polluted commodities for both producers and consumers. The purpose of Economic instruments is to set the full cost through paying the scarcity cost of resource depletion as well as paying the cost of damage for environmental degradation. [9]

Economic instruments are ideally used to integrate environmental aspects and developmental requirements, as well as to integrate economic and environmental policies based on: a) market improvements, b) efficiency or cost minimization, c) flexibility, and d) ability to adapt our self towards the change of circumstances. Economic instruments can be used to provide signs of scarce resources and environmental damage, to encourage an efficient use of resources and to minimize waste in order to create sustainable development[10]

Key for an economic instrument is the ability to make use of market strength and personalinterest, and to build strength in sustainable development. This can be done through changing economic incentives for producers and consumers, as well as making use of a variety of important information available. The scope and procedure for determining the estimated amount of environmental risk can be carried out through a scientific analysis model that has developed very advanced and been standardized in current science and technology. Environmental risk analysis models such as AMDAL and ERA (Ecological Risk Assessment) can decrease the possibility of negative environmental impacts. Through an environmental risk analysis model, it can be estimated how far the scope of funding environmental and economic instruments can be reached by business actors.[11]

\section{Conclusion}

Economic instruments are important to be developed because they strengthen the regulatory system. This approach emphasizes that there is an economic benefit for those in charge of a business and / or activity if they comply with environmental requirements as mentioned by The Constitution and regulation. An economic approach is required to stimulate the person in charge of a business and / or activity to comply with environmental requirements because, among others, avoiding paying penalties or receiving penalties, saving expenses for using efficient practices, and getting incentives if their activities give a positive impact on the efforts to prevent damage and preserve the environment.

In amendment II of the 1945 Constitution, Article $28 \mathrm{H}$ section (1) states that: "Every person has the right to live in physical and spiritual prosperity, to live and to have a good and healthy living environment, has the right to get health services". In the constitution No. 39 of 1999 on Human Rights, it also states the same thing in Article 3 which states: "everyone has the same rights to a good and healthy environment". The importance of the environmental component in supporting and fulfilling the rights of human life. A proper law is a law that contains the values of justice for all people. In this context, so that, law also has a function as a tool of justice (law as a tool to reach justice) in the use of natural and environmental resources. The kind of that justice is

called environmental justice. Environmental justice needs to be scrutinized in the framework of 
the legal basis and implementative regulatory policies related to the fact that the space for marginal people is increasingly pressed.

\section{References}

[1] Y. Pratiwi and J. T. Lingkungan, "Penentuan tingkat pencemaran limbah industri tekstil berdasarkan," J. Teknol., 2010.

[2] UU RI no 32, "UNDANG-UNDANG REPUBLIK INDONESIA NOMOR 32 TAHUN 2009 TENTANG PERLINDUNGAN DAN PENGELOLAAN LINGKUNGAN HIDUP,” 2009. doi: 10.7202/1016404ar.

[3] L. O. A. La Ode Angga and H. Suat, "Legal Responsibility in the Pollution and Environmental Destruction Due to Gold Mining Exploitation in Botak Mountain of Buru Regency," FIAT JUSTISIA, 2019, doi: 10.25041/fiatjustisia.v13no3.1695.

[4] M. I. F. Rahayu, "Sustainable development in the perspective of Sundanese cultural wisdom," $J$. Eng. Appl. Sci., 2017, doi: 10.3923/jeasci.2017.4657.4660.

[5] N. Ruhaeni, "PERKEMBANGAN PRINSIP TANGGUNG JAWAB (BASES OF LIABILITY) DALAM HUKUM INTERNASIONAL DAN IMPLIKASINYA TERHADAP KEGIATAN KERUANGANGKASAAN," $J . \quad H u k . \quad I U S$ QUIA IUSTUM, 2014, doi: 10.20885/iustum.vol21.iss3.art1.

[6] "Pollution prevention and control," 1991.

[7] M. I. FARMA RAHAYU and A. F. SUSANTO, "Environmental Casualties Due to State Policy in Indonesia's National Development (A Portrait of Jatigede Indigenous People Struggle)," Int. Rev. Manag. Bus. Res., 2018, doi: 10.30543/7-1(2018)-18.

[8] M. Desfandi, "MEWUJUDKAN MASYARAKAT BERKARAKTER PEDULI LINGKUNGAN MELALUI PROGRAM ADIWIYATA," SOSIO Didakt. Soc. Sci. Educ. J., 2015, doi: 10.15408/sd.v2i1.1661.

[9] R. Ashari, E. Budianto, and H. Herdiansyah, "Environmental risk assessment on ship repair work at cilegon national shipyard company," 2019, doi: 10.1088/1742-6596/1363/1/012003.

[10] H. Rahim, "Optimisme Pertumbuhan Asuransi Indonesia ; Proyeksi Perkembangan Lima Tahun ( 2014-2018 )," J. Asuransi dan Manaj. Resiko, 2014.

[11] J. Mukono, "Kedudukan Amdal dalam Pembangunan Berwawasan Lingkungan yang Berkelanjutan (Sustainable Development)," J. Kesehat. Lingkung. Unair, 2005. 